\title{
Devkota in Russia
}

-Janga B. Chauhan

"His name is Laxmi Prasad Devkota. His motherland is Nepal. He is a poet."

"He had visited our country as a distinguished guest, given a memorable impression in Taskent Afro-Asian Writers' Conference. Moscow was his dreamland. He enjoyed its beautiful streets, and wrote, 'Moscow is a city of fairytales."”

"A talented Nepali poet, a freedom-lover, a patriot, an architect of words, an anticolonialist and a man of positive action, Devkota was a cordial friend of Soviet Union."

"A poet dies but his work is immortal. Devkota's poems are living examples."

The above remarks were made by the editor of Asia-Africa Today, a monthly publication of Russian Academy (1963, p. 53).

Devkota headed a Nepalese delegation in 1958 to participate in the Afro-Asian Writers' Conference held in the capital city of Uzbekistan, USSR. It was one of the rare moments of glorious representation from Nepal to an international conference. Russian scholar, Ludmila Aganina, a Doctor of Nepali litarautre, has correctly written, " an expert of English language, world civilization and Nepalese culture, Devkota was among the few personalities whom Nepal had nominated for an international conference" (1999, p. 23)

Before the journey to Tashkent, Devkota had been in Soviet Union to participate in an International Youth Festival held in Bukharest, the capital city of Rumania. At the time of Tashkent visit, Devkota was already attacked by cancer, but his active Bodhi, 3 (1), 99-105. ISSN 2091-0479. (C) 2009 Kathmandu University 
participation and scholarly speech gave an excellent image of Nepal. Publications from the Tashkent conference and notes from Ludmila Aganina provide evidences for this fact.

After the conference, Devkota was suggested by the Soviet government to undergo a comprehensive health check in Moscow. For this purpose he had to stay in Moscow hospital for some time. In these circumstances, Ludmila Aganina came in close contact with Devkota. Remembering those days she has written,

When he knew that I was a student of Nepali language and was interested in Nepali literature, he began to tell me about Nepali culture and contemporarty writers. His facial expression was telling me that he had forgotten his deep pain. At the end, with a gentle smile he questioned me, 'In which language do you feel comfortable, English or Nepali?' 'Until now English,' I said. After my answer he told me, "Very good. At the moment I don't have any poems with me. But I will create something for you. Please come tomorrow. (1999, p. 23)

Thus Ludmila Aganina got some of Devkota's poems in English. In the poems of these days we can find his optimism on world peace and brotherhood. Aganina gave one of the poems to Russian poet Jheleznov, who translated it into Russian. Including this poem, a collection of Nepali poems entitled Poems of Nepali Poets was published in 1962 in Russian for the first time. The collection was edited by Aganina herself. Devkota's story "Teej" was also translated into Russian by Aganina and was included in a collection of Nepali stories Love of Mother (1962). "In Moscow" and "Blue Are the Mountains" were among the poems published in Russian translation. Although the Moscow day poems were dedicated to the host country, they are replete with the memories of native nature.

Devkota was in Soviet Union fifty years ago. His visit was a milestone in the history of Nepal - Russia friendship. Krishna

Bodhi, 3 (1), 99-105. ISSN 2091-0479. (C) 2009 Kathmandu University 
Prakash Shrestha, an expert in Russia, pointed out in the preface to Devkota's collection:

May be for someone it is unbelievable, but it is true that the historical speech on Nepal and Nepali literature on the Tashkent Afro-Asian Conference gave birth to a few Russian scholars who later systematically started Nepal studies in Russia. Among them Ludmila Aganina was one. (1999, p. 15) [my translation from Russian]

Aganina was an interpreter for Devkota during the Tashkent conference. She was greatly influenced by his talent. In Moscow, she became more acquainted with multidimensional Devkota. She could not forget Nepal and Nepali people afterwards. She really dedicated her life to study and research on Nepali poetry. She did her doctorate in Nepali poetry from Moscow State University. Her doctoral dissertation was entitled "Man, Society and Religion in Contemporary Nepali Poems." She published a book on history of Nepali literature and presented some scholarly research articles on Nepali literature. Her biographical work on Devkota, Story of Nepali Poet the Great Devkota: Life and Work, became popular among Russian readers. This was the first work of its kind by a foreign writer on a Nepali poet of merits. Devkota was born in Russia in the works of Aganina. Russian readers got a chance to listen a poetic voice of a Nepali heart. Due to the efforts of Aganina, Devkota's selected works were published and popularized in Russia. Influences of both Devkota and Aganina on Russian scholars traced a historical path for a people-to-people friendship between Nepal and Russia. Krishna Prakash Shrestha has called Aganina "a mother of Nepali literature in Russia." She died on 25 December 2000 Nepalis could not get any news of the untimely demise of a cordial friend. Only Nepal-Russia Literary Society dedicated an evening in her commemoration.

When I mention Devkota and Aganina in the context of Russia, I find myself at least in the corner of contributors and feel happy. Devkota travelled through the Trans-Siberian Railway

Bodhi, 3 (1), 99-105. ISSN 2091-0479. (C) 2009 Kathmandu University 
when he was on the way to Bucharest Youth Festival. After more than half a century, I was travelling through the same route. It took me seven days and six nights to reach Beijing from Moscow after participating in the Russian Language Conference in Moscow where I presented my collection of translation in Nepali In the Depth of Russia and other Stories (2005). In that long way, many things danced in my heart including the images of Devkota's poetic journey through the vast Siberian plain of the dense forest.

I met Aganina for the first time in Octobor 1998 in Moscow Friendship House. Even now I remember that historic evening. I was one of her audience for a scholarly presentation on the occasion of the $90^{\text {th }}$ birth anniversary of Devkota. That was also the $40^{\text {th }}$ anniversary of Devkota's visit to USSR. The literary evening was dedicated to Devkota in the auditorium of Roszarubez Center. Aganina was the chief guest. She delivered a lecture on Devkota's life and work and also recited some of Devkota's poems in Russian translation. On the same occasion, scholars, both Russians and Nepalis, shed lights on the contributions of Devkota both to Nepali literature and to Russia-Nepal friendship and cooperation. Equally memorable for the occasion was Irina Smirnova's piano music of some Nepali melodies which created an ambience full of Devkota himself.

This ceremony was monumental. It was when the concept of publishing the collection of Devkota's works in Russian took shape. Ludmila Aganina and Krishna Prakash Shrestha took initiatives and, as a result, Selected Works of L.P. Devkota was published in the following year. This has proved to be an important event in augmenting Nepal-Russia literary relations after the collapse of Soviet Union.

Some of Aganina's remarks on Devkota and his works in Selected Works read as follows:

Bodhi, 3 (1), 99-105. ISSN 2091-0479. (C) 2009 Kathmandu University 
Devkota is compared with Bengali writer Rabindranath Tagore, Hindi chhayavadis, and western romanticists. But he was not a photocopy of others. His writings are original based on his own style, Devkota's style. He loved traditional Nepali folk songs, and wrote poems imbued with Nepali traditions which made him popular among Nepali people. He was always against the Rana autocracy and expressed his anti-Ranarchy voice as an editor of Yugvani. In the last days of his life he was appointed a minister of education, but he was not for a ministerial post. His poetic character could not accept the bureaucratic life.

Nepali Devkota was a rare talent. He is not limited within the country. He is the talent of the world.

Days will go on, many people will leave this world, but the personalities like Devkota never die. They will live in the hearts of people forever. $(1999$, p. 20, 23-26)

We should not forget another name, Yuri Malishev, when we talk about Devkota with reference to Russia. Malishev, a famous cosmonaut twice decorated with the medal 'Hero of Soviet Union,' and the then president of the Society for Russia-Nepal Friendship and Cooperation, wrote in the preface to Selected Works:

Culture has strongly connected the past with the present, and is opening a path to the future.

The present world is changing rapidly. We are standing on the threshold of a meaningful century. So, we must have a humble heart to make this world a common beautiful home. We must not break this world into pieces. For this good cause there are great thinkers, writers, poets, who are actively working. Among them stands Laxmi Prashad Devkota - a talented poet of world civilization.

Bodhi, 3 (1), 99-105. ISSN 2091-0479. (C) 2009 Kathmandu University 
He is liked in our country. He had good knowledge about Soviet Union of multinational and multicultural people. He heartily loved us. He was a patriot and at the same time a world class citizen. His writings are for the whole world. He is universal. So many years passed after his death, but his creativity constantly gives us cordial and lively energy. (1999, p. 10-11)

In 1992, after the collapse of Soviet Union, Malishev visited Nepal. This was not his first visit, though. But this time he had deep pain in his heart. I accompanied him during his travels to Chitwan, Tansen and Pokhara. He tried to enjoy the beauty of nature but the pain inside him could not hide. At least, I could easily read him. He never opened this topic of discussion. He was in Nepal at such times when Russia was not in the condition to continue its glorious achievements in cosmos technology. In Chitwan Jungle Lodge, after dinner, Malishev was trying to hide himself between black and white tresses of moonlight and lantern. He thought that even busy life must spare some pleasure playing with nature. I perceived then that even a cosmonaut could feel poetically; he also had active eyes of an artist and could save the lively sceneries in the canvas of his heart and could make life melodious.

I remember the Tansen evening, with Malishev at the park of Srinagar. He was silent and standing at the blue park giving a deep look towards the dense mountain forest. Suddenly I asked, "What's happening with you?" His answer was thoughtful:

'I'm regulating my nervous system. In this journey of life, I read many events, saw many things, experienced many feelings, and flew in the space. It seems to me that I'm overloaded. Here in this peaceful corner of the earth, I want to forget everything and want not to exist for a while.'

Bodhi, 3 (1), 99-105. ISSN 2091-0479. (C) 2009 Kathmandu University 
This cosmonaut, a citizen of a mechanized metropolitan city, must have been influenced by Devkota's nature poems like "Forest," "Tree," "Mountain Waterfall," "Question and Answer," "Nepali Mountain," "Cloud," and "Bishnumati." Sung against absurdities of life, "The Lunatic," must have had a special tune for him. "Traveller" must have given him a new dimension of human feelings. Malishev said, "Devkota is a universal poet." He was true. Devkota's historical speech to the Tashkent conference proves this:

We have gathered here to acquaint with one another, to know one another closely. Each nation represented here can share a lot with another nation. Today, voices of hearts have filled the hearts of humans. We will accumulate the voices like the tides of the sea, and communicate to the generations to come. (Devkota, 1960, p.179) [translated from Russian]

Devkota wrote, "What aim to take, but to fly and touch a moon?" What a coincidence! He died the same day when the Soviet Luna reached the moon. Maybe the departed soul of the great poet flew to the moon. Aganina remembered the event in this way.

\section{References}

Aganina, L. (Ed.). (1999). Izbrannie Praizvédenia (Selected works). Moscow: Organizatsia Nepalskikh Predprinimatelei V SNG.

Devkota, L. P. (1960). Nepali Literature: Materials on AfroAsian Writers' Conference. Tashkent, Russia.

Shrestha, K. P. (1999). Russiama Nepal ko chhavi (The image of Nepal in Russia). Moscow: Himal Prakashan Guthi.

Bodhi, 3 (1), 99-105. ISSN 2091-0479. (C) 2009 Kathmandu University 